Gabriel FEDORKO

Vieroslav MOLNÁR

Miroslav DOVICA

Nikoleta HUSÁKOVÁ

Ján KRÁL'jr.

Mirosław FERDYNUS

\title{
THE USE OF INDUSTRIAL METROTOMOGRAPHY IN THE FIELD OF MAINTENANCE AND RELIABILITY OF RUBBER-TEXTILE CONVEYOR BELTS IN CLOSED CONTINUOUS TRANSPORT SYSTEMS
}

\section{WYKORZYSTANIE PRZEMYSŁOWEGO METROTOMOGRAFU W UTRZYMANIU I NIEZAWODNOŚCI TAŚM PRZENOŚNIKOWYCH TKANINOWO- GUMOWYCH W PRZENOŚNIKACH TAŚMOWYCH Z ZAMKNIĘTĄ TAŚMĄ}

\begin{abstract}
Closed transport systems have been widely implemented in various areas of bulk solid handling because of their advantages. The unique character of these systems stems from the fact that transported material is fully enclosed by a conveyor belt. To ensure their operational reliability and efficient maintenance during operation, processes occurring inside the belt must be monitored. Early damage identification is very important, if not crucial, for reliable functioning of transport systems. One way to do this is by applying the industrial metrotomography method. The paper presents the research methodology of conveyor belt damage using computer metrotomography. It reports the experimental results for two samples: one with a damaged belt matrix and the other with cracks in the upper surface layer of rubber. The damage in the form of puncture of the transporting belt is also described in the paper.
\end{abstract}

Keywords: metrotomography, closed transport systems, conveyor belt, laboratory tests.

\begin{abstract}
$Z$ powodu swych zalet, systemy transportowe zamknięte, zostaly szeroko wprowadzone i zastosowane w różnch dziedzinach transportu materiałów sypkich. Wynika to z unikalnych cech tych systemów, gdzie transportowany materiat jest w petni otoczony taśma. Aby zagwarantować niezawodność operacyjna i skuteczna konserwację w trakcie eksploatacji, procesy zachodzace wewnątrz taśmy przenośnikowej musza być monitorowane. Identyfikacja uszkodzeń we wczesnym stadium, jest bardzo ważna, jeśli nie rozstrzygajaca, dla przyszłego niezawodnego funkcjonowania systemu transportowego. Jednym ze sposobów identyfikacji uszkodzeń, jest zastosowanie metody metro-tomografii przemystowej. W pracy przedstawiono metodykę badań uszkodzeń taśm przenośnikowych tkaninowo- gumowych z wykorzystaniem metro-tomografii. Zaprezentowano wyniki badań doświadczalnych dwóch próbek, gdzie zniszczeniu uległa osnowa taśmy oraz kolejnej, gdzie zaobserwowano pęknięcia w warstwie wierzchniej gumy. Zostało również opisane zniszczenie w postaci przebicia pasa transportowego
\end{abstract}

Stowa kluczowe: metrotomografia, zamknięty system transportowy, przenośnik taśmowy, testy laboratoryjne.

\section{Introduction}

With increasing environmental awareness of the public as well as international and national laws on emission control it becomes more and more difficult to operate large industrial plants, particularly near residential areas. In the specific case of bulk materials handling in coal power stations, cement plants and steel works, understandable demands with respect to complying with the limits of dust, odour and, in particular, noise emissions require a modern, environmentally friendly design based on the use of very low-noise plants.

Closed transport systems are more and more widely applied in various bulk solids handling businesses. This results from the unique character of these systems, where material is fully enclosed by belt [8]. The use of a closed conveyor for transportation of bulk material gained huge popularity abroad over the past years. The closed conveyor is a modern way of transporting bulk materials [7]. The popularity of the enclosed conveyors lies in their eco-friendliness and cost-effectiveness which means low labour and operating costs [1].The best known representatives of closed transport systems are tubular conveyor belts. In the 1970s Japan Pipe Conveyor Co. Ltd. developed a pipe or tubular belt conveyor which was first installed in 1979 [6]. The problem of tubular belt conveyors has been examined in many research projects, one aspect of this research being traffic routes. Kulagin [9] deals with bending radius of the tubular conveyor in the horizontal plane by computer modelling. Another significant field of research concerning tubular conveyor belts is the behaviour of a transporting belt. Baburski [3] analyses the mechanical properties of conveyor belts at three main stages of production. In his other research, he investigated the effect of pipe conveyor belt pressure on the rollers on its circuit [4]. This type of research requires knowledge 
about material properties of conveyor belts. Mazurkiewicz [11] deals with the problem of identification of strength properties of rubber materials for the purposes of numerical analysis. Rubber as an adhesive base and a construction material is unique, and its properties can vary depending on its composition, additive content, etc. [11].

As already mentioned, there are different types of closed transport systems. Aside from tubular conveyor belts, they also include sandwich conveyors. This type of conveyors was investigated by Alspaugh [2] with respect to latest developments in the belt conveyor technology. Other transport systems also include overhead conveyor belts, U-con belts, and

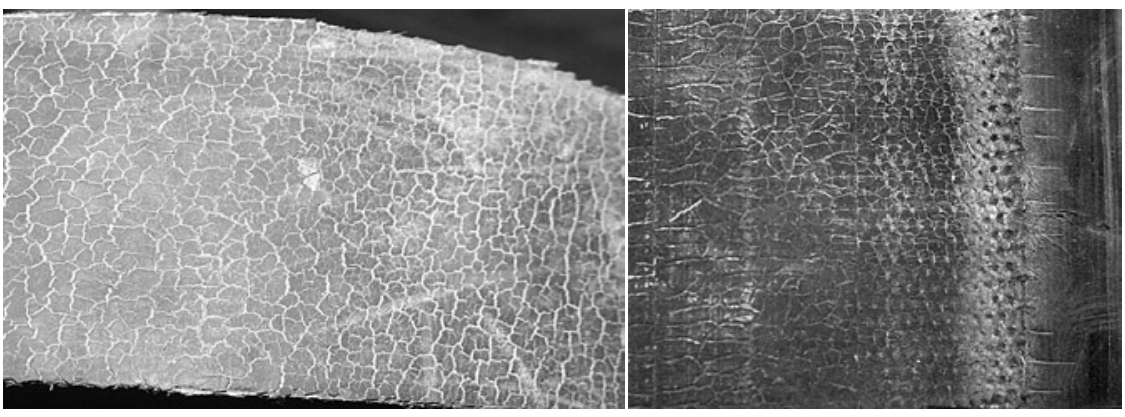

Fig. 2. Violation of homogeneity in the surface area of a conveyor belt used in the closed conveyor belt transport system the like.

The above systems have one feature in common: material is transported using a conveyor belt which generally consists of rubber and various textiles. In order to ensure their operational reliability and effective maintenance, processes occurring inside the belt must be known. This means the knowledge about their inner structure regarding occurrence of undesired degradation processes[13]. This important data is difficult to acquire. One of the methods to do so is to apply the industrial metrotomography method.

\section{Description of conveyors with a closed conveyor belt}

Conveyors with a closed conveyor belt (Fig. 1) have special design and construction. The largest and most important feature of these devices is a conveyor belt folded into a specific shape. A vast majority of these transport systems were designed and made to transport loose and dusty materials. The conveyors can be installed in almost any industry depending on its properties.

Depending on a process, the group of closed conveyor belts includes:

a) tube conveyors,

b) overhead conveyors

c) conveyors with a pressure conveyor belt,

d) U-con conveyors.

In this type of transport system, the conveyor belt has a closed form with various types of forming rolls which differ from each other in their dimensions and construction. The forming rolls are usually arranged at regular intervals along the full length of the travel

route. Their arrangement a)

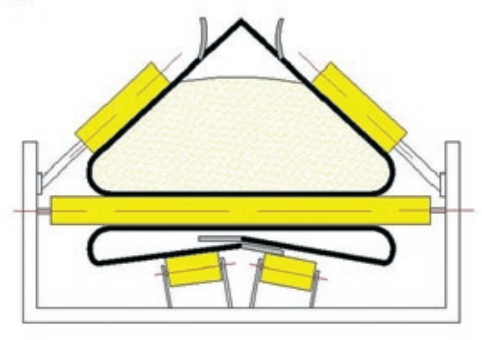

Table 1. Comparison of selected types of damage to rubber-textile conveyor belts in closed continuous transport systems

\begin{tabular}{||l|c|c|c|c||}
\hline \hline & $\begin{array}{c}\text { Outer area of the } \\
\text { conveyor belt }\end{array}$ & $\begin{array}{c}\text { Inner area of the } \\
\text { conveyor belt }\end{array}$ & $\begin{array}{c}\text { Possibility of simple } \\
\text { visual detection }\end{array}$ & $\begin{array}{c}\text { Seriousness of the } \\
\text { disorder }\end{array}$ \\
\hline Textile carcass disorder & No & Yes & Ho & Medigh \\
\hline Penetration of the belt & Yes & Yes & Yes & Medium \\
\hline Homogeneity violation & Yes & Yes & No & Yigh \\
\hline Separation of the belt interior & No & Yes & Yes & Yow \\
\hline Thickness reduction & Yes & No & Yes & Medium \\
\hline Dynamic wear & & &
\end{tabular}

can only differ in the region of their closing and opening, or in the place where the routes are rounded.

As a result of the above, each enclosed conveyor belt of the transport system is cyclically exposed to recurring loads. As a result of time and other factors, damage processes occur in the conveyor belt. Their presence can be most easily identified in the surface areas of conveyor belts, the effect being disruption of belt homogeneity, i.e. cracks occur (Fig. 2). At the same time, reduction in cover layers thickness can be observed. All these processes can be identified and observed once we know about their existence and can thus take adequate and effective measures to redevelop or minimize them.

At this point is seems necessary to focus on damage processes which are not visible at first, but take place in inner layers of the conveyor belt. Usually, there are no visible signs on the surface indicating their existence; sometimes their presence is vaguely signalled at irregular intervals. It is very important that they are noticed and identified early as this can sometimes be crucial for reliable operation of a transport system. In most cases, the detection of internal damage processes is solely based on personal experience of the individuals responsible for maintenance and operation of a particular transport system. b)

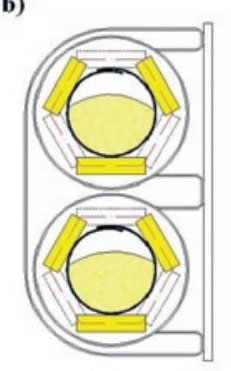

c)

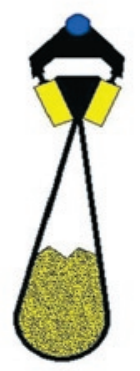

Fig. 1. Examples of continuous transport systems with a closed conveyor belt

\section{Classification of damage in rubber-textile conveyor belts for closed continuous transport systems}

For a reliable operation of closed transport systems with a rubber-textile belt, their users need to identify all negative processes occurring inside the belt or on its surface (Table 1) and subsequently to take adequate and effective measures in order to eliminate their effects. Only in this way can reliable operation of such transport systems be assured.

Table 1 shows that the most serious malfunctioning of belts occurs in their internal region, where it is difficult to identify. Commonly used methods based on experimental measurement are inappropriate and they are only of informative value. At 
present the quality and reliability of rubber-textile conveyor belts maintenance in closed continuous transport systems can be ensured by application of more progressive attitudes enriching our knowledge with three-dimensional visualization of internal structures of these types of rubber-textile conveyor belts. One such widely used is industrial computer metrotomography.

\section{Industrial Computer Metrotomography}

Computed Tomography, X-ray computed tomography (CT) has found its first application in medicine (1970), with the construction of the first scanner (1969). In 1980, CT was used in industry for material analysis and non-destructive testing. It became a revolutionary tool for dimensional metrology, for comparing nominal and actual geometry, i.e. verification of geometrical and dimensional tolerances. At present, the measurement technology is preferably used for parts made of different materials using new technologies, especially complex geometry. Three areas of CT application, i.e. medical purposes, materials analysis and dimensional metrology, are all based on the same physical and mathematical principles, however the impact of various factors needs to be considered.

Using CT (Fig. 3), we can obtain a complete 3D model of a scanned workpiece either in the form of a volume model or a surface model defined from a volume model by creation of a polygonal mesh [10].

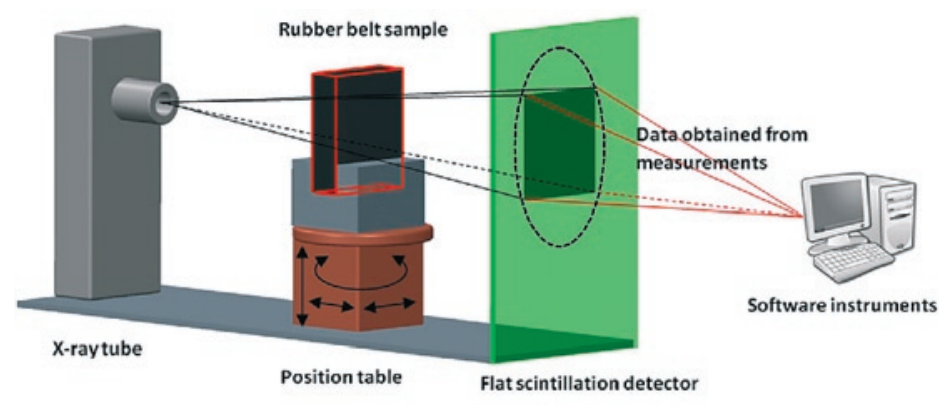

Fig. 3. Principle of arrangement of computed tomography

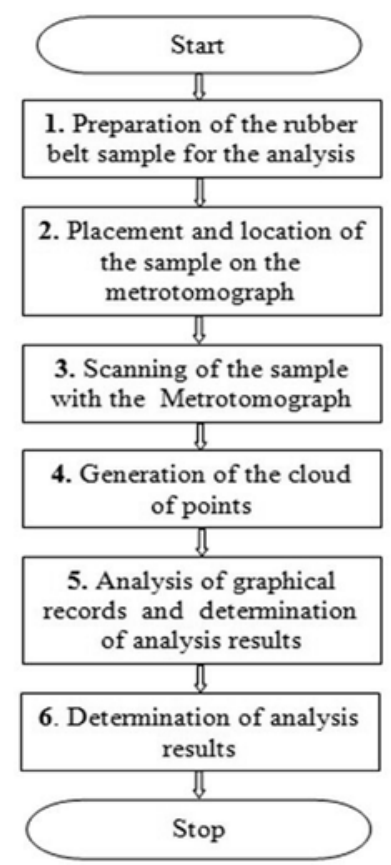

Fig. 4. Activities and procedures for preparing and taking measurements [5]
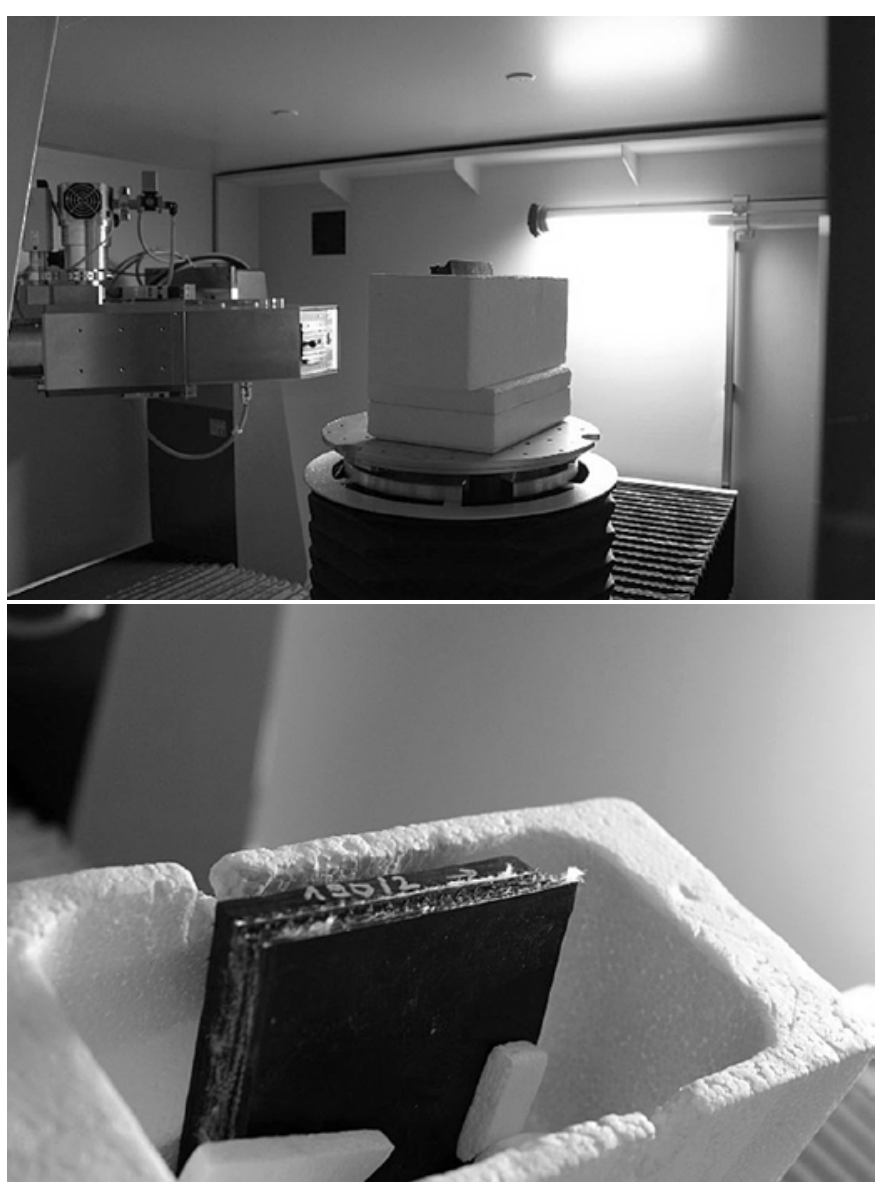

Fig. 5. Location of measured sample in the industrial metrotomograph

The software tools are used both to work with models and to measure dimensional and other metrological applications. However, every software tool provides various algorithms of the measuring strategy in order to define particular measured characteristics.

To obtain a desired result with metrological quality using CT, the following interrelated processes must be performed: scanning, volume data reconstruction, surface determination and evaluation. The individual stages do not include calibration of the measuring machine, as this is performed by the manufacturer [12]. For the purposes of research and commercial utilization, the machine must have a valid certificate with a defined and reported measurement uncertainty.

Fig. 4 presents the description of main activities and procedures to be implemented for the application of industrial tomography methods in the analysis of damage to rubber and textile belts in closed continuous transport systems. The methodology includes activities like preparation of measurement samples, measurement, as well as processing and evaluation of the measured data.

The result of the activities and procedures listed in Fig. 4 is a digital 3D model of the sample from a closed continuous conveyor belt transport system. However, the measurement process and analysis do not stop at this point. The model needs to be processed with the use of software tools. In doing so, a premeditated strategy on how to proceed must be available, i.e. we must know in advance the sample analysis will predominantly focus on.

With rubber-textile conveyor belts it is essential to check their consistency, since it significantly influences a variety of operational factors of the transport system. Above all, textile skeleton fibres must be inspected for any signs of damage. Furthermore, it is necessary to check the belt for possible cavities in each rubber layer and to monitor separation of individual layers that make up 
the whole structure of the conveyor belt. Further measurements depend on requirements of individual operators, operating conditions, transport system and transported material.

\section{Experimental measurements}

The aim of experimental measurements is not limited to generating visualizations of the analysed sample. The sample must be further evaluated in various views, sections and with the possibility of filtering out the individual construction layers.

Fig. 6 shows the front view of the conveyor belt sample enabling us to observe its real structure. Darker colours indicate rubberised textile carcass and the presence of a puncturing layer. In the textile carcass, the disruption of conveyor belt structural integrity can be observed at two points. The damage situated on the left is considerably large. It penetrates numerous carcass plies of the conveyor belt and displays the signs of diagonal spreading. This is a serious damage that needs to be analysed in the longitudinal direction and from the above view.

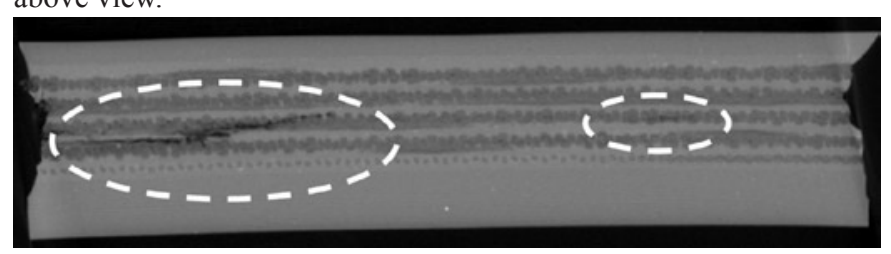

Fig. 6. Front view of the analysed sample of rubber-textile conveyor belt

The detection of such a defect can be significant for maintenance of a transport system and its operational reliability. If detected at an early stage, when it is not extensive, measures can be taken to repair the conveyor belt and to prolong its life.

The other identified defect is significantly smaller, which points to its early stage. However, it is situated very close to the first defect, which is quite an unfavourable situation. If ignored, this might result in interconnection of the defects, leading to significant impairment of the conveyor belt's operating characteristics. The defect is likely to spread further and could lead to general degradation of the conveyor belt and potential damaging of the transport system.

Fig. 7 shows sample analysis in the longitudinal direction. Again, the sample reveals the presence of two clearly visible defects of various sizes and extents. It should be emphasized that the structure of the conveyor belt in the longitudinal direction significantly impacts its strength properties. At this point, besides other loads the conveyor belt is under action of a tensile force. This fact combined with the presence of the defect can lead to a total damage of the conveyor belt, which would cause substantial loss from the economic point of view. It is therefore necessary to analyse such conveyor belts by

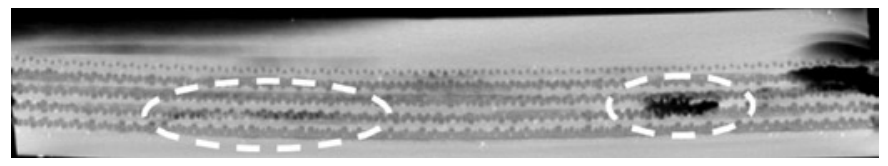

Fig. 7. Side view of the analysed sample of rubber-textile conveyor belt

means of classic experimental measurements, the informative value of which can be highlighted using industrial metrotomography.

The two above mentioned examples are related to identification of very serious defects. Apart from this,_computer metrotomography methods can also be used in the case of less serious damage which is visually identifiable such as formation and presence of cracks in the upper plating layer of the rubber-textile conveyor belt.
Fig. 8 shows the front view of the conveyor belt sample. The view was obtained from the analysis of samples with visible homogeneity disruption in their upper cover layer (in the form of multiple cracks).

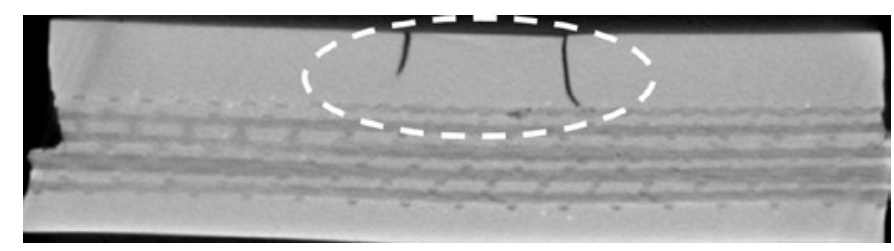

Fig. 8. Front view of the sample material of rubber-textile conveyor belt with cracks in the upper cover layer

The cracks can be observed by conventional visual inspection, a common practice method in the maintenance of closed conveyor belt transport systems.

The figure reveals the presence of two cracks located in the central part of the sample. The crack on the left extends halfway in the upper cover layer while the other crack is a little more extensive and extends almost up to the puncturing insert of the conveyor belt. This information considerably expands the data gathered by visual check. On its basis it can be concluded that the cracks do not directly affect or endanger operational reliability of the transport system. The conveyor belt's internal structure is intact and has no internal defects, hence its strength properties are not at risk. If more surface cracks are present, measures need to be taken to repair the belt.

The conveyor belt can be analysed with software tools which use algorithms for image analysis of bitmap documents. This allows us to analyse top views collected by optical recognition of cracks and evaluation of their hazard degree. This process can be improved using neural networks, as the abstraction of rules from the input and output values can improve the original algorithms.

Fig. 9 shows an example of this way of sample analysis. At first sight a disturbance passing through the textile carcass conveyor belt can be clearly observed. The view enables further detailed visualisation of the structure of the textile carcass conveyor belt. We can clearly see that individual textile fibres are, besides the point of per-

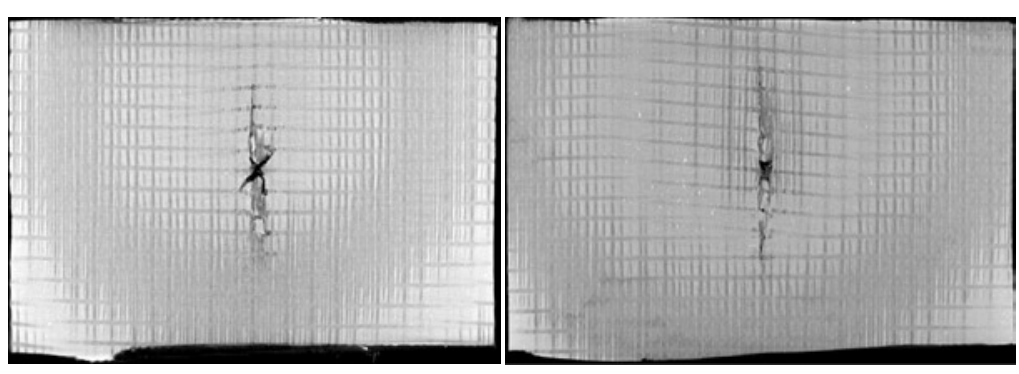

Fig. 9. Top view of analysed sample of rubber-textile conveyor belt showing perforation caused by material load on the conveyor belt

foration, intact. In further analysis it would be necessary to examine problems such as the defect's depth and its potential spread.

\section{Conclusion}

Continuous transport systems with a closed conveyor belt are being applied in more and more industrial areas. Their reliable operation strongly depends on regular and reliable maintenance. In addition to traditional practices, new solutions must be implemented to expand maintenance information base. Such solutions include the use of computer-based metrotomography tools. In the paper we have discussed basic applications for the above method in the field of rubbertextile conveyor belts. It must, however, be emphasized that computer metrotomography can provide a wide range of other data depending on specific requirements (Fig. 10). 

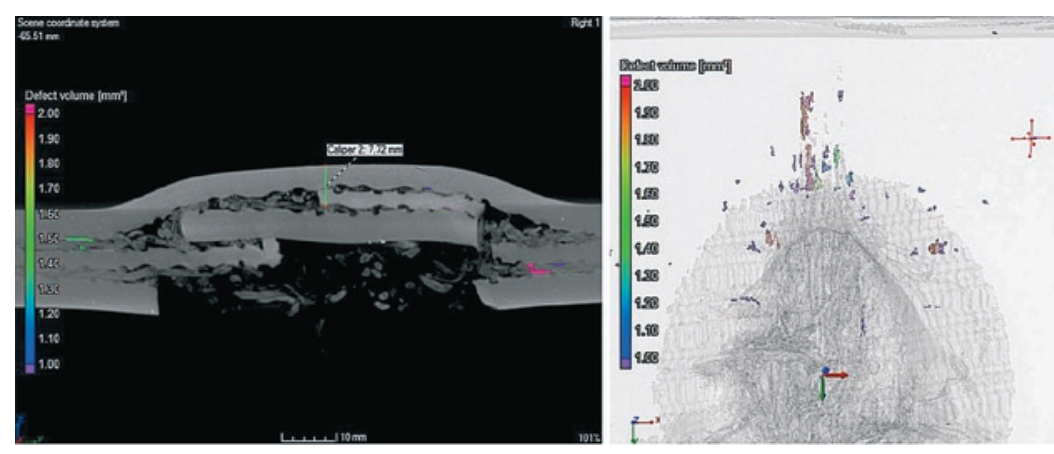

Fig. 10. Examples of other data obtained by sample analysis of rubber-textile conveyor belts

long lasting one. Therefore, it is sufficient if its use is combined with implementation of regular service outages of transport systems when collection of individual samples is possible, e.g. by shortening of the conveyor belt.

A transport system operator will be able to gain valuable information about the current condition of the conveyor belt, and on this basis can continuously plan its successive maintenance and investment costs of acquiring a new conveyor belt.

\section{Acknowledgements}

We would like to thank the Head of the Department of Biomedical Engineering and Measure-

An obstacle to the application of this method is that it cannot be done online during operation of the conveyor. This is not necessary, since most of the damage which can be identified by this method is a ment, Dr hc prof. ing. Jozef ŽIVČÁK, PhD., for his support in writing this paper. The paper is part of the grant projects VEGA 1/0258/14, VEGA 1/0063/16, KEGA 006STU-4/2015, KEGA 018TUKE-4/2016 and APVV-15-0149.

\section{References}

1. Ansari AH. Pipe conveyors advantages, Chemical Engineering World 2005, 40/10: 47-49.

2. Alspaugh MA. Latest Developments in Belt Conveyor Technology. MINExpo 2004, Las Vegas, NV, USA: 2004.

3. Barburski M. Analysis of the mechanical properties of conveyor belts on the three main stages of production, Journal of Industrial Textiles, November 17, 2014, http://dx.doi.org/10.1177/1528083714559567.

4. Barburski M. Analysis of the pipe conveyor belt pressure on the rollers on its circuit, Journal of Industrial Textiles, January 6, 2015, http:// dx.doi.org/10.1177/1528083714567242.

5. Fedorko G, Molnar V, Dovica M, Toth T, Fabianova J. Failure analysis of irreversible changes in the construction of the damaged rubber hoses, Engineering Failure Analysis 2015; 58: 31-43, http://dx.doi.org/10.1016/j.engfailanal.2015.08.042.

6. Ford N. The Pipe conveyor, Quarry Managers' Journal 1996; 5 (23): 27-32.

7. Holt P. Enclosed bulk transport - Tubular/pipe belt conveyor, Bulk Solids Handling 2001, 21: 347-349.

8. Imai A. Pipe Conveyor Development, Benchmark and Future Trend, Bulk Solids India 2011.

9. Kulagin DS. Establishment of bending radius of the tubular conveyor in the horizontal plane by modelling on the computer, Mining Informational and Analytical Bulletin (Scientific and technical journal) 2009; 16 (12): 114-129.

10. Kruth JP, Bartscher M, Carmignato S, Schmitt R, De Chiffre L, Weckenmann A. Computed Tomography for Dimensional Metrology. CIRP Annals- Manufacturing Technology 2011; 60: 821-842, http://dx.doi.org/10.1016/j.cirp.2011.05.006.

11. Mazurkiewicz D. Problems of identification of strength properties of rubber materials for purposes of numerical analysis : a review, Archives of Civil and Mechanical Engineering 2010; 10(1) : 69-84, http://dx.doi.org/10.1016/S1644-9665(12)60131-9.

12. Tóth T, Živčák J, Glittová D. Design of artefact for the verification of the Carl Zeiss Metrotom Computed Tomograph, in: XXI IMEKO World Congress, Prague, Czech Republic, 2015.

13. Trebuňa F, Šimčák F, Bocko J, Trebuňa P. Failure analysis of mechanical elements in steelworks equipment by methods of experimental mechanics, Engineering Failure Analysis 2010; 17: 787-801, http://dx.doi.org/10.1016/j.engfailanal.2009.10.011.

\section{Gabriel FEDORKO \\ Vieroslav MOLNÁR \\ Nikoleta HUSÁKOVÁ}

Faculty of Mining, Ecology, Process Control and Geotechnology

Technical University of Kosice, Letna 9, 04200 Kosice, Slovak Republic

\section{Miroslav DOVICA \\ Ján KRÁL Jr.}

Faculty of Mechanical Engineering,

Technical University of Kosice, Letna 9, 04200 Kosice, Slovak Republic

\section{Mirosław FERDYNUS}

Faculty of Mechanical Engineering, Lublin University of Technology, Nadbystrzycka 36, 20-616 Lublin, Poland

E-mails: vieroslav.molnar@tuke.sk, gabriel.fedorko@tuke.sk, nikoleta.husakova@ tuke.sk, miroslav.dovica@tuke.sk, kral.jan@tuke.sk,m.ferdynus@pollub.pl 